\title{
The Influence of Power and Trust on the Initiation and Duration of Modal Shift Solutions
}

\author{
Sara Rogerson ${ }^{1} *$, Vendela Santén ${ }^{1}$ and Uni Sallnäs ${ }^{2}$ (D) \\ 1 SSPA, SE-400 22 Gothenburg, Sweden; vendela.santen@sspa.se \\ 2 Department of Management and Engineering, Linköping University, SE-581 83 Linköping, Sweden; \\ uni.sallnas@liu.se \\ * Correspondence: sara.rogerson@sspa.se
}

Citation: Rogerson, S.; Santén, V.; Sallnäs, U. The Influence of Power and Trust on the Initiation and Duration of Modal Shift Solutions. Sustainability 2021, 13, 3757. https:// doi.org/10.3390/su13073757

Academic Editor: Daniele Manerba

Received: 26 February 2021

Accepted: 24 March 2021

Published: 28 March 2021

Publisher's Note: MDPI stays neutral with regard to jurisdictional claims in published maps and institutional affiliations.

Copyright: (c) 2021 by the authors. Licensee MDPI, Basel, Switzerland. This article is an open access article distributed under the terms and conditions of the Creative Commons Attribution (CC BY) license (https:/ / creativecommons.org/licenses/by/ $4.0 /)$.

\begin{abstract}
Modal shift to more energy-efficient alternatives, such as from road to rail or sea, is one path to reduce negative environmental effects. Transport providers and shippers have crucial roles in modal choice decisions, and a better understanding of the influence of interorganisational factors on modal shift is needed. The purpose is to increase the understanding of opportunities for modal shifts by exploring the influence of power and trust at the interface between transport providers and shippers. Aspects of power (coercive, reward, legitimate, expert and referent) and trust (contractual, competence and goodwill) influencing modal shifts were identified from interviews with shippers and transport providers in Sweden. During the initiation phase of modal shift, power appears more important, while trust is shown essential for the duration. By proactively suggesting modal shift, transport providers can use expert power to create rewards and referent power, through recognition of their expertise. Building trust, particularly goodwill trust, such as time invested in understanding the other party, transparency about challenges and jointly seeking solutions, is key to establish long-term modal shifts. This paper contributes to modal shift literature with insights on power balances and trust between transport providers and shippers.
\end{abstract}

Keywords: environmentally sustainable logistics; transport provider; logistics service provider; shipper; modal shift; power; trust; interorganisational; interface; interaction

\section{Introduction}

A modal shift from road to more energy-efficient transport modes, such as rail and sea, is one prioritised strategy for coping with sustainability goals [1,2]. Lower use of trucks reduces climate change, and limits congestion on roads and related local emissions, e.g., [3]. Research also shows additional benefits of modal shift, such as the cost effectiveness of despeeding logistics [4], or the cost and delivery times reductions gained from synchromodal solutions, which can include modal shift to rail and sea [5]. Thus, the further use of rail and sea transport should be attractive for companies' environmental work. Despite many incentives for change, the modal shift from road to rail and sea is still slow. For example, European modal split figures for 2016 show a slight decrease since 1995 in the use of rail, inland waters and sea for transportation in comparison with road [6].

There are a number of reasons for the slow progress identified in previous research. For example, Rogerson et al. [7] highlight four types of barriers (regulatory, financial, service quality and market characteristics) in their case study of a modal shift to inland waterways. In a similar vein, Raza et al. [8] find in their literature review that issues within seven categories for a shift to short-range sea shipping (service quality, financial, technical, communication, service and market, regulatory and administrative) have a negative impact upon possibilities for a modal shift. In the context of a shift from road to rail, Elbert and Seikowsky [9] pinpoint economic, quality, infrastructural, management, policy and sustainability barriers. Yet, another reason for the slow progress is that several different actors have an influence on decisions regarding mode of transport, thereby making 
the decision-making process more complicated [10]. Shippers need freight transport to move their goods and they place requirements on that transport [11], while arranging and executing transport is the responsibility of transport providers, since a majority of shippers sub-contract their transport operations [12]. The mode of transport is, indeed, often decided by transport providers or shippers, i.e., the companies sending and receiving goods [13,14], but, as argued by Vierth et al. [10], "it is not always evident from outside who is responsible for selecting the transport solution" (p. 19). Shippers not specifying transport mode but instead giving the transport provider flexibility over the choice of transport mode has been advocated in earlier literature on synchromodal logistics [5], but shippers are not always willing to hand over this decision. Despite the need for both shippers and transport providers to be involved in the search for modal shift solutions, research into modal shifts often belongs to either the supply side or the demand side, and, as argued by Eng-Larsson and Norrman [15], these two sides should not be analysed in isolation. In fact, interactive perspectives on the choice of mode of transport that include both shippers and transport providers have increased [13] and Holguín-Veras et al. [16] emphasize that the freight mode choice is best understood as the outcome of interactions between shippers and transport providers.

A modal shift to more energy-efficient transport modes, indeed, requires the participation of both shippers and transport providers and interaction between them is a prerequisite for success [10]. In fact, Styhre et al. [17] highlight a need to improve relationships between shippers and transport providers, based on their study of modal shifts from a shipper's perspective. In order to achieve this, a better understanding of the interorganisational factors that possibly influence modal shifts is needed. In this paper, we focus on the two theoretical constructs of power, e.g., [18] and trust, e.g., [19] between organisations, because they have been proven to have an impact on the interface between shippers and transport providers, e.g., [20-25]. In Fulconis et al. [20], for example, the power disequilibrium between shippers and transport providers is at the very core of the discussion, and the authors suggest that there are signs that transport providers are on their way towards improving their power position vis-à-vis shippers. Furthermore, Wolf and Seuring [21] argue that LSPs are in a "henchmans's" position in relation to shippers with regard to the inclusion of environmental practices in relationships between them. In the context of trust, Jazairy et al. [23] find that a high level of trust has a positive impact on performance at the interface between shippers and transport providers. In a study of perceptions of both shippers and transport providers, Rajesh et al. [26] find that both actors identify trust as a key success factor for the relationships between them.

Despite the aforementioned contributions to the literature, research that explicitly studies power and trust in the context of modal shifts is scarce, see, e.g., [13]. This paper addresses this gap in the literature, and aims to increase the understanding of opportunities for a modal shift by exploring the influence of power and trust at the interface between transport providers and shippers. This includes illuminating specific aspects of power and trust that are relevant for a modal shift. Further, due to both power and trust being taken into consideration, this also allows for illumination of the interplay between them in the context of modal shift. Indeed, acknowledging that power and trust are complementary [27], and understanding the interplay between them can enable actors in inter-organisational relationships to adjust their interaction to give the desired results [28].

The following chapter describes different phases of change, as well as the concepts of power and trust underlying the conceptual model used in this study. Thereafter, Section 3 outlines methods used, describing interviews conducted. In Section 4 the power bases and trust influencing a modal shift in the interviews are described. In Section 5 the use of power and trust are discussed depending on initiation or duration phase and further the interplay between power and trust. Finally, Section 6 reports on the conclusions of this paper, describing contribution to earlier literature, managerial implications and makes suggestions for further research. 


\section{Conceptual Background}

This chapter motivates the conceptual model chosen for the study, in which phases of logistical change, as well as the concepts of power and trust in interorganisational relationships, are included.

\subsection{Phases of Logistical Change}

A modal shift from road to more energy-efficient transport modes means a change in the logistics system. Change is often considered to be a sequential process, which can be divided into phases that need to be undertaken in a specific order for a change to happen [29]. Examples of studies into logistics and supply chain management that divide change into different phases include collaboration [30], sustainable innovation [31], reconfiguration of supply networks [32] and performance measurement systems [33]. For instance, Hisano Barbosa and Andreotti Musetti [33] suggest three such phases: (1) events that trigger change (why should there be a change and what are the desired outcomes?), (2) a change programme and management (how does change occur and what decisions and activities support the change?) and (3) results of the change (a result of the preceding phases). Based on a number of frameworks, Björklund and Forslund [31] develop a framework for sustainable innovation, including: (1) idea generation, (2) selection of ideas, (3) concept development and (4) implementation and learning. Fawcett et al. [30] propose a framework comprising three stages: (1) unfreezing (acknowledging that change is needed), (2) moving (initiating change), and (3) refreezing (maintaining the change). This paper does not intend to undertake a full review of the phases of change, but the frameworks presented above illustrate several similarities between them. By taking a stance in the stages suggested by Fawcett et al. [30], this paper focusses on two phases: initiation (moving in the words of Fawcett et al.) and duration (i.e., refreezing). Thus, the first step suggested by Fawcett at al. is not in focus, alas it is out of scope for this paper. Specifically, the study at hand addresses situations where the first step has already passed. Thus, the two phases of initiation and duration are in focus and constitute a frame for the presentation of the empirical findings.

\subsection{Bases of Power}

Several definitions of power have been suggested in the literature, e.g., [34-37]. For the purpose of this paper, we rely on the definition given by Gaski [38], who suggests that power is "the ability to evoke a change in another's behavior" (p. 10). The influence of power on business relationships is related to the level of power an actor possesses, as more power means greater opportunities to determine the nature of the exchanges in inter-organisational relationships [39]. For an actor that wants to induce change towards a modal shift, power over other actors could therefore be important.

Various approaches to analysing power in business relationships have been suggested in the literature. For example, Clegg [40] suggests a framework of three interacting circuits (i.e., episodic, dispositional, and facilitative), and Hardy [41] relies on four dimensions of power (i.e., resources, processes, meaning and system). Further, several studies, e.g., [42-46], have relied on the five sources of power suggested by French and Raven [18]. These include reward power (the ability to mediate rewards to a target actor), coercive power (includes punishment of the target), expert power (includes a skill or knowledge desired by the target), referent power (the target values identification with the source), and legitimate power (A belief by the target that the source has a natural right to influence). Since French and Raven's influential paper was published, the sources of power have been modified and extended. Informational power has been added to the list of sources, see, e.g., [47], and in some cases legitimate power has been divided into legal legitimate and traditional legitimate [43,47]. This paper relies on the original framework developed by French and Raven [18] for the identification of power bases.

Sources of power have been categorised in various ways in different studies. Some authors differentiate between economic and non-economic power bases [48] or mediated 
and non-mediated power bases $[43,46]$. Another categorisation distinguishes between coercive and non-coercive power sources, where reward, legitimate, referent and expert power are considered to be non-coercive sources of power [42]. Coercive power is related to punishments, whereas the other four do not involve punishment [42] and can therefore be said to relate to a brighter side of power. Indeed, there are different views in the literature concerning whether power is "good" or "bad" see, e.g., [49,50]. The bad side of power could mean, for example, that the powerful actor takes advantage of its position and acts opportunistically, whereas the good side could mean that a powerful actor uses its position to foster well-functioning relationships [49]. Power can also be used in less visible ways [41]. This paper is not restricted to seeing power as positive or negative, but instead remains open to the possibility that power can be used in both coercive and non-coercive ways to induce modal shifts. The power balance or imbalance between actors is also relevant. Vale et al. [51] exemplify how coercive power is used in a situation with imbalance between actors, while resources to coerce were not available in another situation where there was power balance between the actors [52].

\subsection{Types of Trust}

Closely related to the discussion about the two sides of power is the concept of trust. Power and trust are often seen as interlinked, but in different ways [27,53]. Some authors view power as the opposite of trust [54]. Interestingly, the same author also acknowledges that trust can indeed be established in relationships involving a powerful actor, as long as the weaker actor is being treated fairly [55]. This paper takes this latter view and thus reasons that the use of power for modal shifts does not preclude the simultaneous presence of trust.

As with power, there are several definitions of trust in the literature, see for example [56,57]. We rely on the definition given by Sako and Helper [58], who suggest trust to be defined as "an expectation held by an agent that its trading partner will behave in a mutually acceptable manner" (p. 388). Trust can be classified into different types. For example, Sako [19] differentiates between three different types of trust: contractual, competence and goodwill, all of which fit into the forementioned definition [58]. In a similar vein, Mayer et al. [56] distinguish between ability, benevolence and integrity in their development of the concept of trust. Although phrased differently, these two categorisations are largely similar, as suggested by Arvidsson and Melander [59]. Contractual trust, or integrity, means a belief that participating actors will remain true to the contract. Competence trust, or ability, in turn, entails a belief that an actor has the ability to conduct specific tasks. Finally, goodwill trust occurs when actors are willing to exceed the expected contractual agreements. These three types of trust can be said to be levels of trust, with contractual trust being the lowest level, but as relationships develop, trust can also develop and turn into competence trust or goodwill trust [58].

Trust can, to some extent, be associated with long-term commitment $[57,58]$, which in the words of Axelrod ([60], p. 141) can be seen as "enlarging the shadow of the future". For example, Kwon and Suh [61] found there to be a significant relationship between levels of trust and degree of commitment. Further, long-term commitment was found by Sako and Helper [58] to decrease the amount of distrust in buyer-supplier relationships. Previous research has also identified technical assistance, perceived as a gift from the buyer to the supplier, and operational support to increase levels of trust $[57,58]$. Interestingly, Sako and Helper [58] suggests contrasting results in relation to duration of contracts between interacting actors in automotive industry in Japan versus the US. On the one hand, longterm contracts were found to be essential in the U.S. to complement promises of long-term commitment in order to foster trust. On the other hand, which was the case in Japan, written contracts were associated with lower goodwill trust, and the interorganisational routines were instead of larger importance for trust, also in line with [57]. 


\subsection{Conceptual Model}

Figure 1 depicts the conceptual model of the paper, illustrating how power and trust influence, respectively, the initiation and duration of modal shift solutions. Each block in the model is described in a separate section above. An arrow indicates that there can be interplay between trust and power. This paper takes the perspective, in line with, e.g., $[27,28,53]$, that power and trust can co-exist. Vale et al. [52], for example, found the use of non-coercive types of power to foster trust between stakeholders. The coexistence of power and trust also opens up for the use of trust as a mediating mechanism to decrease effects of power asymmetry [62]. Additionally, one recent study by Cuevas et al. [53] suggests that power asymmetry in fact can result in very trusting relationship. The authors found that the effect of the power asymmetry was decreased by a similar view of the relationship specific goals, i.e., goal congruence, and that this enabled the development of a high level of trust.

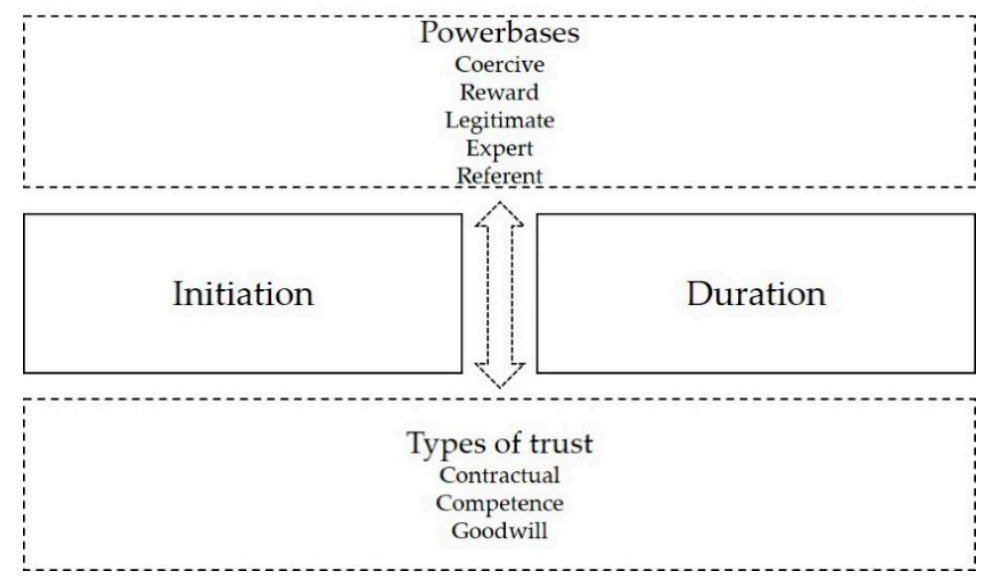

Figure 1. Conceptual model.

\section{Methods}

A qualitative research approach was chosen for the purpose of this paper, i.e., increasing the understanding of possibilities for modal shifts by exploring the influence of power and trust at the interface between transport providers and shippers. This increased understanding was gained in a single case study of this phenomenon. Case studies are relevant when seeking in-depth descriptions [63]. The case study method was appropriate because it could provide detailed descriptions of interactions between transport providers and shippers and their work in relation to modal shift. Semi-structured interviews were conducted with representatives from both actor groups, consisting of three shippers and five transport providers. The companies were selected according to intensity in terms of having experience of modal shifts from either road to rail or road to sea (see Table 1). In line with the explorative aspect of this paper, the sample was driven by a desire to include companies from various different contexts, in order to capture a wide variety of experiences of the influence of power and trust on the modal shift. The shippers are Swedish-based retailers with large flows of commodities and they all engage in logistics activities in different geographical locations in Sweden. The transport providers include large international transport providers offering door-to-door transport solutions for all transport modes, as well as specialised providers of a specific mode. However, each person interviewed represented one area of services (rail or sea) and was able to provide information regarding performing a modal shift and the activities aimed at that modal shift. To capture a wide variety of experiences the companies were chosen to include many examples of modal shift rather than dyads. 
Table 1. Companies and respondents interviewed.

\begin{tabular}{|c|c|c|c|c|}
\hline Company & Mode & Role of Interviewee & Type of Company & Date of Interview \\
\hline Transport provider A & Rail & District manager & $\begin{array}{l}\text { International logistics } \\
\text { service provider }\end{array}$ & $\begin{array}{l}\text { 1. May 2019, } \\
\text { 2. September } 2020\end{array}$ \\
\hline Transport provider B & Rail & CEO & $\begin{array}{l}\text { Provider of rail freight services } \\
\text { in specific geographical regions } \\
\text { in Sweden }\end{array}$ & April 2019 \\
\hline Transport provider C & Rail & $\begin{array}{c}\text { Manager } \\
\text { environmental affairs }\end{array}$ & $\begin{array}{c}\text { International logistics service } \\
\text { provider, division of } \\
\text { freight deliveries }\end{array}$ & May 2019 \\
\hline Transport provider D & Sea & Director ocean freight & $\begin{array}{c}\text { International logistics service } \\
\text { provider, division of } \\
\text { global forwarding }\end{array}$ & April 2019 \\
\hline Transport provider E & Rail & $\begin{array}{l}\text { Strategic account } \\
\text { manager }\end{array}$ & $\begin{array}{l}\text { Provider of rail freight services } \\
\text { in Sweden and to/from Europe }\end{array}$ & May 2019 \\
\hline Shipper A & Sea & Head of supply chain & $\begin{array}{l}\text { Retailer acting within the } \\
\text { Nordic market }\end{array}$ & $\begin{array}{l}\text { 1. April 2019, } \\
\text { 2. May } 2019\end{array}$ \\
\hline Shipper B & Rail & Logistics manager & $\begin{array}{l}\text { Retailer with stores in } \\
\text { northern Europe }\end{array}$ & March 2019 \\
\hline Shipper C & Rail & Head of transport & $\begin{array}{l}\text { Retailer with stores in } \\
\text { northern Europe }\end{array}$ & August 2020 \\
\hline
\end{tabular}

Ten semi-structured interviews were conducted, with each interview lasting 1-1.5 h. A first round of interviews (8) addressed general experiences of modal shifts and explored the influence of power and trust. To increase dependability [64], an interview guide with open-ended questions was used during the interviews. The semi-structured nature of the interviews was deemed important given the explorative purpose of this paper and allowed for follow-up questions where appropriate. The interview guide included questions focused on the companies' goods flows, the drivers and barriers for using rail and sea, activities undertaken to increase sea and rail transport, examples of modal shifts, descriptions of how specific modal shifts were initiated, and the relationship between transport providers and shippers. A second round of interviews (2) focused on specific examples of modal shifts that were identified in the first round and generated in-depth knowledge related to which aspects of power and trust existed in the specific examples. At least two researchers participated at each interview. Detailed notes were taken during each interview and an interview protocol was compiled. The interview protocols were coded using NVivo, first into power and trust, and thereafter into the types of power and trust presented in the frame of reference. In the first step, a deductive analysis of types of power and trust within each interview was conducted. In a second, more inductive, step, the role of power and trust during the phases of initiation and duration were identified. The instances of power and trust were then sorted according to the phases of change in which they were found. All three authors were involved in the analysis and discussion about conclusions, thus improving the research quality through analyst triangulation [65].

\section{Empirical Results}

The empirical results based on the interviews with shippers and transport providers are presented in relation to how the five power bases and the three types of trust influenced a modal shift, starting with power.

\subsection{Power}

In the interaction between transport providers and shippers, a number of power bases were found to influence a modal shift (see Table 2 for an overview). Starting with expert power, this power base recurred frequently in the analysis of the empirical data. Expert 
power can be used to influence a modal shift, primarily during the initiation, but also the duration phase. Transport providers normally know more than shippers about possible transport solutions, including sea and rail, and our examples show that they utilise their expertise when making suggestions and arguing for rail or sea in the shippers' purchasing process. This is mainly used to initiate modal shift. For example, Shipper A described how one transport provider knew of an opportunity to use sea, stressing their own lack of expertise in sea transport and their reliance upon the transport provider's knowledge when implementing a new sea transport solution. For the duration the expertise means that the transport providers facilitate the arrangements of the sea transport, as expressed by Shipper A: "They keep the contact with vessels and shipping companies". Furthermore, Transport provider B experienced that expertise in the niche of rail transport attracted shippers which did not know what rail solution would best fit them and thus can be used to initiate modal shift: "They call and ask if I can transport it". However, the shippers need to acknowledge this skill in order for transport providers' expertise to be powerful.

Table 2. The power bases influencing a modal shift.

\begin{tabular}{|c|c|c|c|}
\hline Type & Examples of Relevance for Modal Shift & Phase & Interview \\
\hline \multirow{4}{*}{ Expert Power } & \multirow{4}{*}{$\begin{array}{l}\text { Transport provider knows more about } \\
\text { possible transport solutions } \\
\text { Shipper(s) lack knowledge } \\
\text { regarding sea/rail } \\
\text { Being first to make suggestions } \\
\text { Transport provider has an extensive } \\
\text { set of offers }\end{array}$} & Initiation, Duration & $\begin{array}{c}\text { Shipper A } \\
\text { Transport provider A, B, C, D }\end{array}$ \\
\hline & & Initiation & Shipper A \\
\hline & & Initiation & Transport provider $\mathrm{A}, \mathrm{C}$ \\
\hline & & Initiation & $\begin{array}{l}\text { Shipper A, B, C } \\
\text { Transport provider E }\end{array}$ \\
\hline \multirow{4}{*}{ Reward Power } & \multirow{2}{*}{$\begin{array}{c}\text { Improved environmental performance } \\
\text { Lower costs }\end{array}$} & Initiation, Duration & \multirow{4}{*}{$\begin{array}{l}\text { Shipper A, B } \\
\text { Transport provider A, } \\
\text { Shipper A } \\
\text { Shipper C } \\
\text { Transport provider A } \\
\text { Shipper C }\end{array}$} \\
\hline & & Initiation, Duration & \\
\hline & Increased sales & Initiation & \\
\hline & Award contract & Duration & \\
\hline \multirow{3}{*}{ Coercive Power } & \multirow{3}{*}{$\begin{array}{c}\text { Setting requirements and } \\
\text { controlling demands } \\
\text { Shippers threaten to substitute provider } \\
\text { Provider only offers one } \\
\text { solution/alternative }\end{array}$} & Initiation & \multirow{3}{*}{$\begin{array}{c}\text { Shipper C } \\
\text { Transport provider A } \\
\text { Shipper A, C } \\
\text { Transport provider A }\end{array}$} \\
\hline & & Duration & \\
\hline & & Initiation, Duration & \\
\hline Referent Power & Contacted based on reputation & Initiation & $\begin{array}{c}\text { Shipper C } \\
\text { Transport provider A, B, D }\end{array}$ \\
\hline \multirow{4}{*}{ Legitimate Power } & \multirow{4}{*}{$\begin{array}{c}\text { Daring to think of new solutions } \\
\text { Selecting the market leader } \\
\text { Dependence due to integration/joint history } \\
\text { Desire/company culture to reduce } \\
\text { road transport }\end{array}$} & Initiation & Transport provider B \\
\hline & & Initiation & Transport provider E \\
\hline & & Initiation, Duration & Shipper C \\
\hline & & Initiation, Duration & Transport provider A \\
\hline
\end{tabular}

Even so, transport providers can establish a base of expert power by being the first to make suggestions regarding initiating the use of rail and sea transport. The transport providers describe how such ambitions exist, with the budding interest in environmental concerns among shippers being a potential door opener for suggesting more energyefficient transport modes. As Transport provider C expressed it: "Even if the customers do not ask, bring an emission report and show to get a discussion going". Still, one of the shippers also pinpointed that such initiatives are missing.

Having an extensive range of offers, i.e., a broad area of expertise, can also be a means to attain expert power for transport providers seeking to initiate a modal shift. Since rail and sea transport solutions often also require a road stretch, shippers are often interested in door-to-door solutions. Transport providers that can provide such a door-to-door solution, which may encompass multiple modes, can then suggest rail or sea without the shipper 
needing to contact multiple transport providers. If the shipper is not interested in how the transport is achieved, the transport provider could decide to use rail or sea without the shipper being asked. As Transport provider A expressed it: "Many of the customers [shippers] for whom we use rail are probably not even aware of it".

Reward power was also found. A modal shift to rail or sea can provide rewards for both shippers and transport providers, mainly through the improved environmental performance of the transport but in some instances also through lower costs. In the interviews, both shippers and transport providers expressed interest in reducing their environmental footprint. The shippers could actively seek a rail or sea alternative from a transport provider, thus providing a reward for themselves. Alternatively, transport providers could use the benefits in the arguments they make to shippers for a modal shift, and through the increased use of rail and sea, realise an improved environmental performance for the shippers' transport. Similar logic applies when lower costs can be achieved through a modal shift. For example, Shipper A emphasised the reward of reduced transport costs by shifting goods from road to sea, and added that environmental benefits were a bonus. Shipper B expressed that: "Environment is the main reason". The rewards may be an argument for initiating a modal shift, but they also remain and can be an argument for keeping the new transport solution, i.e., the duration of the modal shift.

Coercive power was found to be powerful for a modal shift, even though few examples were found. Generally, shippers have the upper hand over transport providers by virtue of awarding contracts, e.g., [20]. Shippers can use coercive power in their purchasing process when setting requirements for the transport providers; for example, by specifically asking for suggestions by rail in order to initiate new solutions, which was done by Shipper C. Furthermore, for the duration of a modal shift, both shippers and transport providers described how there is a threat of substitution, i.e., that the shipper will select a different transport provider. Shipper A exemplifies this: "If they do not deliver, they will be replaced." Closely linked to the threat of substitution is a short-sighted focus on cost on the shipper's side, and transport providers report such a focus to be a barrier to modal shifts. A short-sighted focus on costs increases the threat of substitution, leaving little room for investments in the time and resources needed for a modal shift. Transport provider A stated that the focus on short-term costs leads them to not work with certain shippers. In particular, the cost focus is more apparent in certain industries.

Interestingly, coercive power applied by transport providers towards shippers was also noted. One of the transport providers interviewed (Transport provider A) had decided to push the shippers towards the use of rail, thus applying coercive power to initiate a modal shift. In this situation, Transport provider A made it clear to the shippers that rail was the only option provided. This meant that customers who were not willing to adapt to this change had to choose another transport provider to access the desired service, expressed as "those customers are thus referred to other transport providers" (Transport provider A). For shippers, the new rail service meant adapting to earlier pick-up times, as well as later delivery times, which not all of them were willing to accept. Nevertheless, most of the shippers remained with the transport provider and participated in the modal shift. Not providing an alternative also had an impact on the duration of the modal shift, meaning that it was more difficult for shippers to stop using rail.

Some instances of referent power were found to have an impact on modal shift solutions. This is related to the contact between shippers and transport providers, specifically because transport providers describe how they are contacted by shippers based on their reputation. When this happens, due to the desire of shippers to use a transport provider that is well-known for its sea or rail experience, transport providers are able to drive a modal shift through referent power. The transport providers may want to establish such a reputation in order to attract customers. For example, Transport provider B described how its reputation regarding rail solutions often led to being contacted by shippers that had ambitions of initiating rail: "They have heard that we are active in [specific geographical region] and look us up". 
There were also some aspects of legitimate power influencing modal shifts. From the shipper's perspective, continuing with well-established road solutions may be seen as more legitimate than making a change to rail or sea. Transport provider B described how logistics managers at shippers that were new to their role were more willing to discuss initiation of a modal shift, in particular if they had previous experience of other modes. In such cases, they often asked questions like: "Do we have the right transport solution? Why are we not using rail?" Furthermore, transport providers have seen a trend towards increased interest in more sustainable transport solutions. Although examples are still sparse, among both shippers and transport providers, where a company culture exists for sustainable transport, it can drive both the initiation of a modal shift and maintaining the use of rail or sea. For example, Transport provider A described contacting a large shipper due to its company culture including sustainable development, and thereby having a positive attitude to rail. For the duration of a modal shift, it may also be considered more legitimate for a shipper to continue working with an existing supplier, especially if it is a successful interaction. Shipper C specifically addressed the value of having integrated systems so that crucial information can be shared easily, and such a historical interaction makes it legitimate to continue.

\subsection{Trust}

All three types of trust (contractual, competence and goodwill) appear useful for influencing a modal shift, both when initiating one and in the duration phase (see Table 3). For contractual trust, guaranteeing long-term commitment, the length of the business agreements, additional services contracted, system integration and fulfilling the service agreement were all found to be important for a modal shift.

Table 3. The types of trust influencing a modal shift.

\begin{tabular}{|c|c|c|c|}
\hline Type & Examples of Relevance for Modal Shift & Phase & Interview \\
\hline \multirow{5}{*}{ Contractual Trust } & Guaranteed long-term commitment & Initiation, Duration & Shipper B \\
\hline & Length of business & \multirow{2}{*}{ Initiation, Duration } & \multirow{4}{*}{$\begin{array}{l}\text { Shipper A } \\
\text { Transport provider A, B, C, } \\
\text { Shipper A, C } \\
\text { Shipper C }\end{array}$} \\
\hline & agreements/relationships & & \\
\hline & Additional services contracted & Initiation, Duration & \\
\hline & Fulfilling service agreements & Duration & \\
\hline \multirow{4}{*}{ Competence Trust } & Transport provider knowledgeable about & & \multirow{4}{*}{$\begin{array}{c}\text { Shipper A } \\
\text { Transport provider C, D } \\
\text { Shipper A } \\
\text { Transport provider B, C }\end{array}$} \\
\hline & shipping/rail options & Initiation & \\
\hline & Proactive suggestions from & Initiation, Duration & \\
\hline & transport provider & mutration, Duration & \\
\hline \multirow{7}{*}{ Goodwill Trust } & Jointly seeking solutions & Initiation & \multirow{7}{*}{$\begin{array}{c}\text { Shipper A } \\
\text { Transport provider A, D } \\
\text { Shipper A, C } \\
\text { Transport provider A, D } \\
\text { Shipper A, C } \\
\text { Shipper A, C } \\
\text { Transport provider A } \\
\text { Shipper C } \\
\text { Shipper A, B } \\
\text { Transport provider A }\end{array}$} \\
\hline & Invested in understanding each other & Initiation, Duration & \\
\hline & Spirit for new solutions/Entrepreneurship & Initiation & \\
\hline & Prepared to make adjustments & Initiation & \\
\hline & Information sharing by system integration & Duration & \\
\hline & Honesty and transparency & & \\
\hline & regarding challenges & Initiation, Duration & \\
\hline
\end{tabular}

Both shippers and transport providers mentioned that long-term commitment was important for daring to make changes, such as investments. Guaranteeing a long-term commitment can act as an enabler of a modal shift, and the ways of guaranteeing longterm commitment showed up differently among the interviewed companies. For example, Shipper B, which had large goods flows and a strong interest in rail solutions, created contractual trust in the long-term duration of a rail service and terminal functions at locations close to their major distribution centre, by guaranteeing goods volumes, location and long-term commitment in contract agreements with its transport provider and other actors 
involved. From the perspective of transport providers, Transport provider A emphasised the importance of long-term commitment from their customers, both for initiating a modal shift and making it last: "We can work together to develop it over the years. But we need a longer period of time. If they terminate the contract after only nine months... it removes the incentive" (Transport provider A).

The length of business agreements is important and is distinctly different from a long-term commitment see, e.g., [58]. As shown in these examples, there can be a mutually explicit long-term commitment even when the signed contract is only for a short period of time. This is exemplified by Shipper A, which introduced a short sea shipping solution with only a one-year contract with their new transport provider. Even so, the intention was to build a long-term relationship, and both parties put effort into the relationship during the initial phase to demonstrate that they were serious in their commitment. Additionally, the intention to forge a long-term commitment was demonstrated through a contract for additional warehouse services, set up for a longer time period. This highlights how other service agreements can make the contractual trust stronger, and be important for maintaining the modal shift over time.

In order to achieve contractual trust between the shipper and transport provider, it is also important that the transport provider can fulfil the agreed contract. Shipper $C$, which is striving to use rail as much as possible, mentioned that for a modal shift to rail to last, for them it is of utmost importance that the transport quality is high; specifically, it is crucial that delivery times to stores are met. When the promised service levels are not met, the consequences are severe for the transport provider. This was exemplified by a situation in which a transport provider suggested a new rail solution for the shipper. The new solution was tested, but after two weeks, the shipper concluded that the service being delivered was not good enough: the delivery time was only met to satisfaction on one out of ten days. The test was cancelled, and the old road transport solution resumed. The relationship between the parties was negatively affected by this service failure and the trust in the transport provider to deliver well-functioning rail solutions was depleted.

Trust in competence was the most frequently noted of the three types of trust. The general opinion of the interviewed transport providers was that knowledge levels regarding the use of sea and rail transport are low among many shippers. Shipper A, who clearly expressed limited shipping competence, demonstrated a clear confidence that the transport provider has the required expertise regarding using these modes of transport. Based on this trust in competence, the shippers expect transport providers to make proactive suggestions in order to initiate a modal shift. In the successful examples of modal shifts given in the interviews, the transport providers did play a large role during the initiation phase to suggest a solution. For example, Shipper A described that: "Our partner had the contacts or an idea". However, we noted that the transport providers do not always take this proactive step. Shipper C shared such experiences, i.e., a situation in which one of the largest transport providers of rail services never contacted them to suggest rail solutions, even though the shipper had specifically requested it. Instead, the shipper had to contact the provider to start a dialogue. Unfortunately, the transport provider in this case could not meet the shipper's expectations of competence and proactivity, and did not show any sign of being willing to put effort into finding a solution for the shipper.

Trust in terms of goodwill was also exemplified in the interviews, and acted as an enabler for identifying suitable modal shifts during the initiation phase. It was also important for the duration of the modal shifts.

To identify when a modal shift is most suitable, and how to set up such a solution, the transport providers and shippers need to be jointly seeking solutions: the shippers' knowledge regarding goods flows and characteristics, and the transport providers' knowledge regarding transport alternatives are both needed in order to find beneficial transport solutions and achieve a modal shift. In order to achieve such joint competences, there is a need to invest in understanding each other; hence, a level of goodwill trust is required. While Shipper A highlighted the importance of entrepreneurship and open-mindedness, 
Transport provider $C$ stressed the need to invest time in a dialogue in order to come up with good suggestions-"the transport offer should meet a certain level of quality and price based on the customer's needs, and the customer knows what works in their logistics setting". One way of creating this dialogue was to arrange workshops together with the shippers, both during the initial phase (current and new customers) and to ensure the ongoing improvement of current solutions, which is important for the duration phase. In this type of workshop setting, the inclusion of other functions was highlighted: "Other functions at the shippers need to be involved, such as purchasing, production and logistics, otherwise it will not work out" (Transport provider C). The same view was shared by Transport provider A, who stated "this is not a one-man show", expressing the value of the involvement of the shipper's management board and several functions at the provider when a modal shift from road to rail was successfully initiated. There were also a few examples of shippers that were willing to make adjustments to requirements that were important to them, such as lead time and pick-up time, which enabled the modal shift, as an outcome of the dialogue. Further, sharing information by integrating the systems between both parties is acknowledged as a success factor for achieving a smooth logistics solution, as experienced by Shipper C.

As stressed by Shipper A, open and honest discussions between the parties were important for getting the new sea transport solution in place. Shipper B also stressed the importance of openness, and described an alliance with their transport provider: "it was important to dare to be transparent". Furthermore, Transport provider A explained how an open dialogue regarding problems had been successful in creating a long-term relationship and sustaining the duration of a modal shift. If the shipper asked: "Do you know how to do this?" Transport provider A would answer: "No ... but we will solve it and, if not, I will tell you that we cannot solve it". Being open about what is possible and what can go wrong was stressed as an important part of creating goodwill trust, including, if a failure occurs, raising the question: "what can we do to make everything all right again?" (Transport provider A).

\section{Discussion}

The findings outlined above suggest that both power and trust at the interface between shippers and transport providers can influence modal shifts. As for power, the empirical results suggest that all five types of power bases (expert, coercive, referent, legitimate and reward) are relevant in the context of modal shifts, although some appear to be more prominent than others for shippers and transport providers, respectively (for an overview see Figures 2-5). Expert power is most prominent for transport providers, while coercive power more for shippers. Similarly, all three types of trust appear to be relevant for modal shifts. Taking both power and trust into consideration, it is of interest to resolve how these two constructs can be utilised by both shippers and transport providers. There also appears to be a difference in how power and trust influence the modal shift, depending on the phase of logistical change. In line with the frame of reference, phases of change can be separated into the initiation and duration of modal shift solutions. Interestingly, both shippers and transport providers can initiate a modal shift, but the means of doing so in terms of power and trust appears to differ. Figures 2-5 illustrate the ways in which power and trust can influence a modal shift in the two phases of initiation and duration. The figures can be seen as an extension of Tables 2 and 3, and highlight those aspects of power and trust that the findings reveal as most prominent during the two phases of change. 


\begin{tabular}{|l|l|l|}
\cline { 2 - 3 } \multicolumn{1}{c|}{} & \multicolumn{2}{|c|}{ INITIATING MODAL SHIFT } \\
\hline POWER & $\begin{array}{l}\text { Shipper } \\
\text { Reward power: Award } \\
\text { Contract based on fulfilling } \\
\text { requirements for } \\
\text { energy efficiency } \\
\text { Coercive power: Setting } \\
\begin{array}{l}\text { requirements for modal } \\
\text { shift }\end{array}\end{array}$ & $\begin{array}{l}\text { Transport provider } \\
\text { Expert power: Skill to } \\
\text { Suggest and market } \\
\text { rail/sea } \\
\text { Coercive power: Rail or } \\
\text { sea as only option } \\
\text { Referent power: Reputation } \\
\text { for rail/sea }\end{array}$ \\
\hline
\end{tabular}

Figure 2. - Power during the initiation phase of a modal shift.

\begin{tabular}{|c|l|l|}
\cline { 2 - 3 } \multicolumn{1}{c|}{} & \multicolumn{2}{|c|}{ INITIATING MODAL SHIFT } \\
\hline \multirow{1}{*}{ TRUST } & $\begin{array}{l}\text { Shipper } \\
\begin{array}{l}\text { Goodwill trust: Willingness } \\
\text { to share information, listen } \\
\text { to alternatives and make } \\
\text { adjustments to } \\
\text { requirements }\end{array}\end{array}$ & $\begin{array}{l}\text { Transport provider } \\
\text { Competence trust: Proactive } \\
\text { suggestions } \\
\text { Goodwill trust: Invest time } \\
\text { in under-standing needs } \\
\text { and matching solutions } \\
\text { Think new }\end{array}$ \\
\cline { 2 - 3 } & $\begin{array}{l}\text { Shipper and Transport provider } \\
\text { Contractual trust: Long-term commitment and } \\
\text { guarantees from shippers and transport providers } \\
\text { Goodwill trust: jointly seek solutions }\end{array}$ \\
\hline
\end{tabular}

Figure 3. - Trust during the initiation phase of a modal shift.

\begin{tabular}{|c|l|l|}
\cline { 2 - 3 } \multicolumn{1}{c|}{} & \multicolumn{2}{|c|}{ DURATION OF MODAL SHIFT } \\
\hline \multirow{3}{*}{ TRUST } & $\begin{array}{l}\text { Shipper } \\
\begin{array}{l}\text { Competence trust: Sharing } \\
\text { information to facilitate } \\
\text { understanding and } \\
\text { transport }\end{array}\end{array}$ & $\begin{array}{l}\text { Transport provider } \\
\text { Goodwill trust: Transparency } \\
\text { regarding challenges and } \\
\text { improvements, honesty }\end{array}$ \\
\cline { 2 - 3 } & \multicolumn{2}{|c|}{ Shipper and Transport provider } \\
& $\begin{array}{l}\text { Goodwill trust: Investing in relation-ships, joint } \\
\text { continuous improvements and problem-solving }\end{array}$ \\
\hline
\end{tabular}

Figure 4. - Trust during the duration phase of a modal shift.

\begin{tabular}{|l|l|l|}
\cline { 2 - 3 } \multicolumn{1}{c|}{} & \multicolumn{2}{c|}{ DURATION OF MODAL SHIFT } \\
\hline POWER & $\begin{array}{l}\text { Shipper } \\
\text { Coercive power: Threat of } \\
\text { Substituting transport } \\
\text { provider }\end{array}$ & $\begin{array}{l}\text { Transport provider } \\
\text { Expert power: Knowledge of } \\
\text { transport solution and } \\
\text { shipper's system } \\
\text { Legitimate power: Positive } \\
\text { experiences }\end{array}$ \\
\hline
\end{tabular}

Figure 5. - Power during the duration phase of a modal shift.

\subsection{Initiation of a Modal Shift}

Starting with the initiation phase, power does seem to play an important role in enabling modal shift solutions to come about, which is in line with previous work, e.g., [15]. Previous research suggests a power advantage of shippers over transport providers [20,25], which indicates that the initiation of a modal shift should come from shippers. Our findings both support and contradict this assumption. Shippers can, indeed, initiate change through their power advantage, for example by setting requirements during the purchasing process 
for using specific modes (coercive power), and rewarding transport providers that offer a modal shift in accordance with the shippers' wishes (reward power). This is in line with, amongst others, Bask et al. [66] and Sallnäs [25], who also found that customer pressure influences the adoption of environmental practices, such as modal shifts. In such situations, expert power exerted by the transport provider stands out as vital to support the initiation of a modal shift. Transport providers can possess expert power by knowing about possible transport solutions, while shippers lack knowledge regarding sea and rail. Transport providers can thus use their expert power to make themselves attractive to shippers and be rewarded with a contract.

In contrast to the assumption that shippers should be the ones to initiate a modal shift, our findings also illustrate situations in which transport providers may very well be the ones who drive the change. This is in line with, for example, Kogg [67], who suggests that "greening the supply chain is not the prerogative of the big and powerful" (p. 55). Transport providers can, through the utilisation of coercive power, offer modal shifts to shippers that are already part of their customer base. Despite their assumed power disadvantage [20,25], transport providers can rely on aspects such as expert power and referent power to induce coercive power. In doing so, the transport provider risks losing customers who are not willing to make the suggested change, but by emphasising the components of trust that are presumably already a part of those relationships, transport providers have the ability to convince customers to stay. Such an example was found for Transport provider A. Very few customers ended up not accepting the modal shift solution in that example, thus illustrating the very interesting possibility that transport providers could initiate modal shifts.

Furthermore, transport providers can use their expert-power advantage to initiate a modal shift by making proactive suggestions about rail or sea solutions. They can then gain expert power in the eyes of the shipper by presenting an extensive set of offers. Despite its seeming importance, expert power alone in the hands of the transport provider does not appear to be sufficient for initiating a modal shift. Firstly, it is often found in combination with other power bases possessed by the transport provider. For example, having expert power can also bestow referent power, i.e., becoming recognised for multi-modal solutions and extensive offers. Secondly, there needs to be a desire on the part of the shippers to commit to a modal shift. The promise of a contract, utilised through reward power by the shipper, can act as the igniting spark. Research suggests that reward power and coercive power are essentially two sides of the same coin [49], although the empirical results more clearly suggest that reward power is important during the initiation phase, while coercive power can be used to "punish" transport providers by not giving them the contract.

However, for transport providers to initiate change, the level of trust needs to be higher than when the shipper drives the change. This could be related to the power advantage that shippers are often presumed to have [20]. Our findings indicate that shippers' trust in transport providers is crucial for them to agree to a modal shift, but also that transport providers' trust in shippers was important for investing in the relationship and arranging the transport. One important aspect is the goodwill trust of the shipper, in terms of willingness to create a dialogue with the transport provider, share information, listen to alternatives and, if necessary, make adjustments to requirements. Such dialogue goes hand in hand with goodwill trust from the transport provider's side, and the willingness to invest time to understand the shipper's needs in order to match them with suitable solutions. The shipper's long-term commitment is also an important contractual trust element during the initiation phase. If the shipper can show the transport providers that they do not only see them as a short-term contract holder to be easily exchanged at the end of the contract period, the transport providers' motivation to put in the extra effort to create suitable, and possibly new and unique, solutions for the specific shipper could be increased. Hence, the long-term commitment is very important in building trust, in line with the examples in [58].

Furthermore, the shippers' lack of knowledge regarding rail and sea options, as described above in relation to expert power and competence trust, appears to be a barrier 
that is associated with changing from what you know to what you do not know, which hence seems like a less legitimate choice. It was pinpointed in this paper that managers with experience from other companies, and of other modes than road, were more interested in investigating opportunities for rail or sea. A higher level of knowledge on the part of shippers could thus increase the legitimate power of transport providers, and increase their potential to initiate modal shifts. This is in agreement with the observation that users of a transport mode have a more positive view of it than non-users, as explained in [68]. Flodén et al. [69] and Styhre et al. [17] also describe a lack of knowledge of different modes as a barrier to modal shifts. Styhre et al. [17] describe how their own inexperience with sea transport can make it difficult for shippers to initiate modal shifts, for example, being able to identify when it is suitable.

Although the empirical results reveal the necessity of trust during the initiation phase, power does seem to be more clearly distinguished during this particular phase. In the duration phase, the findings indicate that the opposite is true, and this will be discussed further in the following section.

\subsection{Duration of Modal Shift}

Trust between the shipper and transport provider has been identified as being very important for the duration of modal shift solutions. Goodwill trust in terms of investments from both parties in the relationship could create good conditions for jointly solving upcoming challenges, which may be crucial for making continuous progress, and developing the solution further. Shippers' sharing of information, as well as transport providers' transparency about challenges, are keys to such continuous development. That sharing information, in terms of "instant and transparent communication", builds trust in a 3PL-shipper relationship is also found by Jazairy et al. [23], who also found that mutual development of solutions were a key.

Furthermore, the findings suggest that power still has a role to play in the duration phase, albeit smaller than during the initiation phase. Interestingly, coercive power was also found to be present in the duration phase, because the threat of substitution is a harsh reality for many transport providers. The threat of substitution can impede investments in long-term solutions for new rail or sea set-ups, and thus act as a barrier to modal shifts. It is mainly the duration of a modal shift that is hindered by the potential substitution of transport providers, but it can also influence willingness on the transport provider's side to initiate a modal shift. The change towards a modal shift can be highly complex, and several barriers have been identified in previous literature [7-9], in particular transport solutions utilising sea and rail have been criticised for having poor lead times and limited delivery precision. Coercive power in the form of the threat of substitution has the negative effect of creating a greater risk for the transport provider when engaging in a modal shift compared to maintaining traditional road transport solutions.

The findings also suggest that being afraid of falling into too great a dependency on a particular transport provider can act as a limiting factor for the duration of a successful modal shift. Such behaviour can hamper the willingness to invest in the relationship, such as in terms of goodwill trust activities. On the other hand, it may be considered more legitimate for a shipper to continue to work with their existing transport provider, particularly if their systems are integrated. In such a case, transport providers rely, to some extent, on their legitimate power. If the shipper is well integrated with the transport provider, there is a greater chance that they will both get the utmost out of their interaction, with efficient and well-performed transport operations, including modal shift solutions, and long-term relationships. Building trust enabling integration is relevant to synchromodality since Giusti et al. [5] describe that integration platforms intended to enable stakeholders to interact, share data and communicate are crucial to the success of synchromodality. They further argue that such integration needs to bring advantages for all stakeholders. Thus, trust is important so that stakeholders feel safe in that there is win-win solutions and no harm to each other's interests. 


\subsection{The Interplay between Power and Trust}

As can be derived from the discussion above, trust and power can be seen as complementary forces for the initiation and duration of a modal shift. This is in line with previous research, which acknowledges that power and trust operating simultaneously can contribute to successful interaction between actors, e.g., [28,53], and Horak and Long [27] concluded that power and trust can be both mutually complementary and dependent. One example is if the strategic goals of the shipper and transport provider coincide. In such a case, the incentives for both parties form the basis for joint discussions regarding a modal shift, as in the example where Transport provider A made the strategic change of only offering rail. In this case, the transport provider and a shipper dealing in large volumes of goods were both striving towards improving environmental performance. Thus, reward power (environmental performance) was a positive factor in generating competence trust. Furthermore, trust plays a role when the initiation of a modal shift stems from power. When initiating a modal shift, trust is needed for the other party to listen, and from there derive solutions that will work for both parties. For example, when Transport provider A applied coercive power and offered rail as the only solution, a few of its customers decided to change to another transport provider that could provide road transport. The decision to stay or to change may be influenced by trust, as shown by the willingness of shippers to take part in joint discussions and adapt their requirements.

This paper highlights the expert power that transport providers can exert due to the often low level of knowledge amongst shippers regarding rail and sea transport solutions. In line with [62], findings illustrate how competence trust can balance this lack of knowledge and lead to suggestions and solutions, both more proactively from the transport provider and jointly between the shipper and transport provider. It is not always obvious how to distinguish between these two ways of influencing the modal shift. One possible method is by judging it from the overall level of power and trust. The power created by having expertise in a modal shift solution may build on the fact that little trust exists, whereas competence trust relies on an open dialogue between two parties.

Our findings show that the level of trust at the interface between a shipper and a transport provider will determine the characteristics of the power bases needed to initiate a modal shift. When goodwill trust exists between the shipper and transport provider, both will be open to discussing suitable modal shift solutions. For example, the shipper will listen to proactive suggestions from the transport provider and will consider the adjustments that are necessary in order to achieve a modal shift, such as changes in service requirements to fit what sea or rail can offer. Meanwhile, if there is little or no trust between shippers and transport providers, coercive power may instead be used to initiate a modal shift; for example, the shipper may request one specific mode or solution, or the transport provider may only offer rail or sea solutions so that shippers have to adapt to such a setup. Transport providers could use their expert power to transfer shippers more forcefully to rail and sea transport, thereby initiating change.

\section{Conclusions}

This paper set out to explore the influence of power and trust at the interface between transport providers and shippers. Based on interviews with shippers and transport providers, the findings suggest that both power and trust do influence the possibilities for achieving a modal shift, and that there are interdependencies between them (this is in line with, e.g., [28]). Furthermore, the findings illustrate that power and trust appear to have different influences on modal shifts during the initiation phase and the duration phase of the change. Specifically, power appears to be the more important construct during the initiation phase, while trust is of greater importance in the duration phase. While the findings do point to this conclusion, it is important to note that there is an interplay between power and trust during both the initiation and the duration phases. In addition, shippers and transport providers appear to utilise different power bases in the change towards a modal shift, where transport providers are found to rely on all five power bases 
(coercive, reward, expert, legitimate and referent), while shippers rely more heavily on coercive power and reward power.

This study contributes to the literature on interaction in supply chains, with its inclusion of transport providers and its theoretical perspective of power and trust [70]. Further, this paper contributes to the research into modal shifts primarily by its explicit focus on the two concepts of power and trust. Few, if any, studies have previously applied these two theoretical perspectives in a specific modal shift context, and it thus addresses the call from Bask and Rajahonka [13] for stronger theoretical contributions in modal shift research. The paper thus adds to previous studies into modal shifts, such as Eng-Larsson and Norrman [15], who find the initiation of a modal shift to be dependent on the power advantage of shippers from the perspective of the transport provider. From a trust perspective, the paper adds to, e.g., Monios and Bergqvist [24], who identify trust as vital for the success of a "virtual joint venture" between a shipper and a transport provider, and provide insights to the findings of Giusti et al. [5], who find cooperation to be essential in synchromodality, but that building trust among stakeholders is challenging. From a wider perspective of sustainability, the findings confirm the results of Meqdadi et al. [71], as this paper also finds that power influences adoption and trust facilitate implementation in such a context. Finally, the paper contributes to earlier studies on facilitators and barriers for modal shifts, e.g., [7-9], by describing how power balances and trust can influence modal shifts.

In terms of managerial implications, our findings show that additional opportunities for the initiation and duration of a modal shift would appear if trust were built up to a greater extent, in terms of contractual trust (long-term commitment), competence trust (sharing information, jointly seek solutions and problem solving) and goodwill trust (listening to alternatives, making adjustments to requirements and investing in the relationship with the transport provider). This is largely due to the power that shippers already apply in their interactions with transport providers. Transport providers and shippers can use the findings of this paper to create better conditions for modal shift through their use of power and trust in the interaction between them. Transport providers can utilise both power and trust to a greater extent in the initiation and duration of modal shifts. It can be a strategy to show the market what they have to offer in terms of modal shift solutions and that they want to take the initiative to suggest rail or sea, even when shippers have not asked for it, i.e., proactivity and thinking along new lines. Thus, expert power can be used to create both rewards and referent power, i.e., becoming well-known for their expertise. Shippers need to understand that their use of coercive power, specifically the threat of substituting transport provider if they underperform, can hinder the duration of modal shift, by making transport providers reluctant. Further, both transport providers and shippers need to understand the importance in building trust for realizing modal shift. In particular dialogue and investing in understanding the other party (goodwill trust) is important to initialize modal shift, while being transparent about challenges and information-sharing are important for a continued good relationship and a long-lasting modal shift.

Like all studies, this paper has its limitations, but this also brings to light avenues for further research. All companies interviewed reside in Sweden, and comparisons with other countries would be valuable. Further, even though the paper takes the theoretical perspectives of both power and trust, these concepts are largely treated as two individual concepts. The results do, however, reveal an intertwined relationship between power and trust in the context of modal shifts. Additional research could focus more deeply on the interplay between power and trust during modal shifts, in order to extend our understanding of the circumstances under which they complement each other (in line with Horak and Long [27]), and when they become contradictory forces. Further, while this study aimed at multiple examples of modal shift, power balances and trust, and therefore interviewed multiple companies, it does not provide the in-depth insights that a dyadic relationship may provide. Another avenue for further research is therefore to study power and trust in specific relationships between shippers and transport providers who focus 
on modal shifts. Although this paper includes both the shippers' and transport providers' perspectives, the studied companies are treated as separate entities without ties between them. By studying dyads, triads or networks, the nuances of power and trust could be further illuminated. An interesting context for such studies is synchromodality, in which many stakeholders are involved [5]. The findings are based on interviews conducted 20192020, and a final suggestion for additional research is longitudinal studies of modal shifts, because such an over-time perspective can reveal how power and trust change and evolve.

Author Contributions: All authors contributed to all parts of the paper. Main author and second author had the largest roles in the investigation part. All authors have read and agreed to the published version of the manuscript.

Funding: This research was funded by the Swedish Energy Agency, grant number 46953-1.

Institutional Review Board Statement: Not applicable.

Informed Consent Statement: Informed consent was obtained from all subjects involved in the study.

Data Availability Statement: The data that support the findings of this study are available on request from the corresponding author. The data set are not publicly available due to the privacy of the respondents.

Conflicts of Interest: The authors declare no conflict of interest. The funders had no role in the design of the study; in the collection, analyses, or interpretation of data; in the writing of the manuscript, or in the decision to publish the results.

\section{References}

1. Woodburn, A.; Whiteing, A. Tranferring Freight to "Greener" Transport Modes. In Green Logistics: Improving the Environmental Sustainability of Logistics, 3rd ed.; McKinnon, A., Browne, M., Piecyk, M., Whiteing, A., Eds.; Kogan Page: London, UK, 2015; pp. 148-164.

2. Pinchasik, D.R.; Hovi, I.B.; Mjøsund, C.S.; Grønland, S.E.; Fridell, E.; Jerksjö, M. Crossing Borders and Expanding Modal Shift Measures: Effects on Mode Choice and Emissions from Freight Transport in the Nordics. Sustainability 2020, 12, 894. [CrossRef]

3. Chen, S.; Wu, J.; Zong, Y. The Impact of the Freight Transport Modal Shift Policy on China's Carbon Emissions Reduction. Sustainability 2020, 12, 583. [CrossRef]

4. McKinnon, A.C. Freight Transport Deceleration: Its Possible Contribution to the Decarbonisation of Logistics. Transp. Rev. 2016, 36, 418-436. [CrossRef]

5. Giusti, R.; Manerba, D.; Bruno, G.; Tadei, R. Synchromodal logistics: An overview of critical success factors, enabling tech-nologies, and open research issues. Transp. Res. Part E Logist. Transp. Rev. 2019, 129, 92-110. [CrossRef]

6. Commission, E. EU Transport in Figures; Imprimerie Centrale: Luxembourg, 2018.

7. Rogerson, S.; Santén, V.; Svanberg, M.; Williamsson, J.; Woxenius, J. Modal shift to inland waterways: Dealing with barriers in two Swedish cases. Int. J. Logist. Res. Appl. 2019, 23, 195-210. [CrossRef]

8. Raza, Z.; Svanberg, M.; Wiegmans, B. Modal shift from road haulage to short sea shipping: A systematic literature review and research directions. Transp. Rev. 2020, 40, 382-406. [CrossRef]

9. Elbert, R.; Seikowsky, L. The influences of behavioral biases, barriers and facilitators on the willingness of forwarders' decision makers to modal shift from unimodal road freight transport to intermodal road-rail freight transport. J. Bus. Econ. 2017, 87, 1083-1123. [CrossRef]

10. Vierth, I.; Lindgren, S.; Lobig, A.; Matteis, T.; Liedtke, G.; Burgschweiger, S.; Niérat, P.; Blanquart, C.; Bogers, E.; Davydenko, I.; et al. FALCON Handbook: Understanding What Influences Modal Choice; CEDR Contractor Report 2017-07; CEDR: Brussels, Belgium, 2017.

11. Rogerson, S. Influence of freight transport purchasing processes on logistical variables related to $\mathrm{CO}_{2}$ emissions: A case study in Sweden. Int. J. Logist. Res. Appl. 2017, 20, 604-623. [CrossRef]

12. Lammgård, C.; Andersson, D. Environmental considerations and trade-offs in purchasing of transportation services. Res. Transp. Bus. Manag. 2014, 10, 45-52. [CrossRef]

13. Bask, A.; Rajahonka, M. The role of environmental sustainability in the freight transport mode choice: A systematic literature review with focus on the EU. Int. J. Phys. Distrib. Logist. Manag. 2017, 47, 560-602. [CrossRef]

14. Meers, D.; Macharis, C.; Vermeiren, T.; Van Lier, T. Modal choice preferences in short-distance hinterland container transport. Res. Transp. Bus. Manag. 2017, 23, 46-53. [CrossRef]

15. Eng-Larsson, F.; Norrman, A. Modal shift for greener logistics-Exploring the role of the contract. Int. J. Phys. Distrib. Logist. Manag. 2014, 44, 721-743. [CrossRef]

16. Holguín-Veras, J.; Xu, N.; De Jong, G.; Maurer, H. An Experimental Economics Investigation of Shipper-carrier Interactions in the Choice of Mode and Shipment Size in Freight Transport. Netw. Spat. Econ. 2011, 11, 509-532. [CrossRef] 
17. Styhre, L.; Rogerson, S.; Santén, V. Modal shift to short sea shipping from a transport purchasing perspective. In Proceedings of the NOFOMA Conference, Oslo, Norway, 13-14 June 2019.

18. French, J.R.; Raven, B. The Bases of Social Power. In Studies in Social Power; Cartwright, D., Ed.; University of Michigan Press: Ann Arbor, MI, USA, 1959.

19. Sako, M. Price, Quality and Trust: Inter-Firm Relations in Britain and Japan; Cambridge University Press: Cambridge, UK, 1992.

20. Fulconis, F.; Nollet, J.; Paché, G. Purchasing of logistical services: A new view of LSPs' proactive strategies. Eur. Bus. Rev. 2016, 28, 449-466. [CrossRef]

21. Wolf, C.; Seuring, S. Environmental impacts as buying criteria for third party logistical services. Int. J. Phys. Distrib. Logist. Manag. 2010, 40, 84-102. [CrossRef]

22. Makukha, K.; Gray, R. Logistics Partnerships Between Shippers and Logistics Service Providers: The Relevance of Strate-gy. Int. J. Logist. Res. Appl. 2004, 7, 361-377. [CrossRef]

23. Jazairy, A.; Lenhardt, J.; Von Haartman, R. Improving logistics performance in cross-border 3PL relationships. Int. J. Logist. Res. Appl. 2017, 20, 491-513. [CrossRef]

24. Monios, J.; Bergqvist, R. Using a "virtual joint venture" to facilitate the adoption of intermodal transport. Supply Chain Manag. Int. J. 2015, 20, 534-548. [CrossRef]

25. Sallnäs, U. Coordination to Manage Dependencies between Logistics Service Providers and Shippers: An Environmental Perspective. Int. J. Phys. Distrib. Logist. Manag. 2016, 46, 316-340. [CrossRef]

26. Rajesh, R.; Pugazhendhi, S.; Ganesh, K.; Yves, D.; Koh, S.C.L.; Muralidharan, C. Perceptions of service providers and customers of key success factors of third-party logistics relationships-an empirical study. Int. J. Logist. Res. Appl. 2011, 14, 221-250. [CrossRef]

27. Horak, S.; Long, C.P. Dissolving the Paradox: Toward a Yin-Yang Perspective on the Power and Trust Antagonism in Collaborative Business Relationships. Supply Chain Manag. Int. J. 2018, 23, 573-590. [CrossRef]

28. Ireland, R.D.; Webb, J.W. A multi-theoretic perspective on trust and power in strategic supply chains. J. Oper. Manag. 2007, 25, 482-497. [CrossRef]

29. van Hoek, R.; Johnson, M.; Godsell, J.; Birtwistle, A. Changing chains: Three Case Studies of the Change Management Needed to Reconfigure European Supply Chains. Int. J. Logist. Manag. 2010, 21, 230-250. [CrossRef]

30. Fawcett, S.E.; Fawcett, A.M.; Watson, B.J.; Magnan, G.M. Peeking Inside the Black Box: Toward an Understanding of Supply Chain Collaboration Dynamics. J. Supply Chain Manag. 2012, 48, 44-72. [CrossRef]

31. Björklund, M.; Forslund, H. Exploring the sustainable logistics innovation process. Ind. Manag. Data Syst. 2018, 118, 204-217. [CrossRef]

32. Ross, A.; Venkataramanan, M.A.; Ernstberger, K.W. Reconfiguring the Supply Network Using Current Performance Da-ta. Decis. Sci. 1998, 29, 707-728. [CrossRef]

33. Hisano Barbosa, D.; Andreotti Musetti, M. The Use of Performance Measurement System in Logistics Change Process: Proposal of a Guide. Int. J. Product. Perform. Manag. 2011, 60, 339-359. [CrossRef]

34. Dahl, R.A. The concept of power. Syst. Res. Behav. Sci. 2007, 2, 201-215. [CrossRef]

35. Emerson, R.M. Power-Dependence Relations. Am. Sociol. Rev. 1962, 27, 31. [CrossRef]

36. Cox, A.; Ireland, P.; Lonsdale, C.; Sanderson, J.; Watson, G. Supply Chains, Market and Power-Mapping Buyer and Supplier Power Regimes; Routledge: London, UK, 2002.

37. Stannack, P. Purchasing Power and Supply Chain Management Power-Two Different Paradigms?-A Response to Ramsay's 'Purchasing power' (1995). Eur. J. Purch. Supply Manag. 1996, 2, 47-56. [CrossRef]

38. Gaski, J.F. The Theory of Power and Conflict in Channels of Distribution. J. Mark. 1984, 48, 9-29. [CrossRef]

39. Cook, K.S. Exchange and Power in Networks on Interorganizational Relations. Sociol. Q. 1977, 18, 62-82. [CrossRef]

40. Clegg, S.R. Frameworks of Power; SAGE Publications: New York, NY, USA, 1989.

41. Hardy, C. Understanding Power: Bringing about Strategic Change. Br. J. Manag. 1996, 7, S3-S16. [CrossRef]

42. Hunt, S.D.; Nevin, J.R. Power in a Channel of Distribution: Sources and Consequences. J. Mark. Res. 1974, 11, 186-193. [CrossRef]

43. Maloni, M.; Benton, W.C. Power Influences in the Supply Chain. J. Bus. Logist. 2000, 21, 49-73.

44. Flynn, B.B.; Zhao, X.; Huo, B.; Yeung, J.H.Y. We've Got the Power! How Customer Power Affects Supply Chain Relation-ships. Bus. Horiz. 2008, 51, 169-174. [CrossRef]

45. Belaya, V.; Hanf, J.H. The Two Sides of Power in Business-to-Business Relationships: Implications for Supply Chain Man-agement. Mark. Rev. 2009, 9, 361-381. [CrossRef]

46. Zhao, X.; Huo, B.; Flynn, B.; Yeung, J.H.Y. Effect of Customer Power on Supply Chain Integration and Performance. In Managing Global Supply Chains Relationships: Operations, Strategies and Practices; Flynn, B., Morita, M., Machuca, J., Eds.; Business Science Reference: New York, NY, USA, 2010.

47. Johnson, J.L.; Sakano, T.; Cote, J.A.; Onzo, N. The Exercise of Interfirm Power and its Repercussions in U.S.-Japanese Channel Relationships. J. Mark. 1993, 57, 1. [CrossRef]

48. Etgar, M. Selection of an Effective Channel Control Mix. J. Mark. 1978, 42, 53-58.

49. Belaya, V.; Hanf, J.H. The Dark and the Bright side of Power: Implications for the Management of Business-to-Business Rela-tionships. Agric. Food Econ. 2016, 4, 1-17. [CrossRef]

50. Kumar, N. The power of power in supplier-retailer relationships. Ind. Mark. Manag. 2005, 34, 863-866. [CrossRef] 
51. Vale, J.; Ribeiro, J.; Branco, M.C. A Relational Approach to the Creation and Deterioration of Intellectual Capital in Me-taOrganizations: The Case of a Seaport. Int. J. Transp. Econ. 2018, 45, 123-147.

52. Vale, J.; Ribeiro, J.A.; Branco, M.C. Intellectual Capital Management and Power Mobilisation in a Seaport. J. Knowl. Manag. 2017, 21. [CrossRef]

53. Cuevas, J.M.; Julkunen, S.; Gabrielsson, M. Power symmetry and the development of trust in interdependent relationships: The mediating role of goal congruence. Ind. Mark. Manag. 2015, 48, 149-159. [CrossRef]

54. Kumar, N. The Power of Trust in Manufacturer-Retailer Relationships. Harvard Bus. Rev. 1996, 74, 92-106.

55. Kumar, N.; Scheer, L.K.; Steenkamp, J.-B.E.M. The Effects of Supplier Fairness on Vulnerable Resellers. J. Mark. Res. 1995, 32, 54-65. [CrossRef]

56. Mayer, R.C.; Davis, J.H.; Schoorman, F.D. An Integrative Model of Organizational Trust. Acad. Manag. Rev. 1995, 20, 709-734. [CrossRef]

57. Dyer, J.H.; Chu, W. The determinants of trust in supplier-automaker relationships in the US, Japan, and Korea. J. Int. Bus. Stud. 2010, 42, 10-27. [CrossRef]

58. Sako, M.; Helper, S. Determinants of trust in supplier relations: Evidence from the automotive industry in Japan and the United States. J. Econ. Behav. Organ. 1998, 34, 387-417. [CrossRef]

59. Arvidsson, A.; Melander, L. The Multiple Levels of Trust when Selecting Suppliers-Insights from an Automobile Manufac-turer. Ind. Mark. Manag. 2020, 87, 138-149. [CrossRef]

60. Axelrod, R. The Evolution of Cooperation; Basic Books: New York, NY, USA, 1984; p. 241.

61. Kwon, I.-W.G.; Suh, T. Factors Affecting the Level of Trust and Commitment in Supply Chain Relationships. J. Supply Chain Manag. 2004, 40, 4-14. [CrossRef]

62. Ran, B.; Qi, H. Contingencies of power sharing in collaborative governance. Am. Rev. Public Adm. 2018, 48, 836-851. [CrossRef]

63. Yin, R.K. Case Study Research: Design and Methods; Sage Publications: Thousand Oaks, CA, USA, 2009.

64. Bryman, A.; Bell, E. Business Research Methods, 3rd ed.; Oxford University Press: New York, NY, USA, 2011.

65. Patton, M.Q. Qualitative Research E Evaluation Methods, 3rd ed.; Sage Publications: New York, NY, USA, $2002 ;$ p. 598.

66. Bask, A.; Rajahonka, M.; Laari, S.; Solakivi, T.; Töyli, J.; Ojala, L. Environmental Sustainability in Shipper-LSP Relationships. J. Clean. Prod. 2018, 172, 2986-2998. [CrossRef]

67. Kogg, B. Greening a Cotton-textile Supply Chain. Greener Manag. Int. 2003, 2003, 52-64. [CrossRef]

68. Vannieuwenhuyse, B.; Gelders, L.; Pintelon, L. An online decision support system for transportation mode choice. Logist. Inf. Manag. 2003, 16, 125-133. [CrossRef]

69. Flodén, J.; Bärthel, F.; Sorkina, E. Transport Buyers Choice of Transport Service-A Literature Review of Empirical Results. Res. Transp. Bus. Manag. 2017, 23, 35-45. [CrossRef]

70. Ülgen, V.S.; Björklund, M.; Simm, N.; Forslund, H. Inter-Organizational Supply Chain Interaction for Sustainability: A Systematic Literature Review. Sustainability 2019, 11, 5488. [CrossRef]

71. Meqdadi, O.; Johnsen, T.E.; Johnsen, R.E. The role of power and trust in spreading sustainability initiatives across supply networks: A case study in the bio-chemical industry. Ind. Mark. Manag. 2017, 62, 61-76. [CrossRef] 